\title{
Analysis of Basic Motion Skill Learning Model of Upper-Class Elementary School Students Based on Games
}

\author{
Nevi Hardika* \\ Physical Education Health and Recreation \\ IKIP PGRI \\ Pontianak, Indonesia \\ *nevihardika@gmail.com
}

\author{
Moch. Asmawi, James Tangkudung \\ Sport Education \\ Jakarta State University \\ Jakarta, Indonesia \\ asmawi.moch1@gmail.com, james24061952@gmail.com
}

\begin{abstract}
The purpose of this study is to find out Learning Model for Basic Motion Skills of Elementary School Class Students Based on Games. The research method used is descriptive method with the survey form. The subject of this research is the upper-class elementary school with the object of research as many as 10 upper-class Sports Teachers in the city of Pontianak. Data collection techniques using teacher observation sheets and data analysis techniques in the basic game skills-based learning model uses qualitative analysis techniques and quantitative descriptive percentages. The results of completeness of learning activities of teachers in carrying out the learning process there are two elementary school sports teachers with a mastery of learning by $80 \%$ categorized as good, while for the category of quite overall there are seven sports teachers with each level of mastery learning by $73 \%$ as many as three sports teachers and $67 \%$ as many as four sports teachers and for categories of less than $60 \%$ as many as one sports teacher. So the total overall results of learning completeness with an average of $70.66 \%$ are categorized enough with a minimum value of nine and a maximum value of twelve. The conclusion reached is the level of mastery of teaching performance is less than the minimum standard of $75 \%$ and the need for new products in game-based learning models to improve the results of the learning process when cooperative and competitive practice in the field.
\end{abstract}

Keywords: basic motion skills, game, high school primary students, learning model

\section{INTRODUCTION}

Learning movement skills is one part of physical education learning in schools which is a process of interaction of students with educators and learning resources in a learning environment [1]. The purpose of physical education basic aims to; physical development, motion development and mental development [2]. The importance of basic motion lessons given in primary schools must bring fresh air to improve movement patterns in physical education learning activities [3].

Physical education and health are also subjects in elementary schools that have been in school since the beginning of school entry [4]. Therefore it must be a professional service for teachers or educators who request part of sports science and physical lessons that must be provided to students ranging from elementary school to high school level [5]. Following by the Decree of the Minister of Education and Culture of the Republic of Indonesia No.0413 / U / 87. The purpose of physical education is basically aimed at; physical development, motion development, mental development, and mental development. Basic movement skills is a person's ability in physical education that aims to make students skilled in physical activity.

Basic Motion Skills are a level of mastery of quality in body movement activities [6]. Motion skills are a foundation of movement in the process of movement which involves the coordination of several parts of the body or all parts of the body to function properly [7]. Motor skills in sports have three categories which are very important roles in moving that is: a) locomotor capabilities, b) non-locomotor capabilities, c) manipulative abilities. One of the goals of implementing physical education and sports in health in primary schools is to improve good and correct basic movement skills [8].

Basic human movement skills that cannot be released are walking, running, jumping and throwing [9]. The pattern of basic movement skills that is patterned is a process of learning motion that has been learned since elementary school students. Basic motion from the road, running and jumping are the basic movements that need to be developed in elementary school besides other basic movements.

High school elementary students are children at the age of 10-12 years who have major developments in social life and motor development. High school elementary students are children at the age of 10-12 years who have major developments in social life and motor development. Elementary school students often experience obstacles or besides students also have growth and development such as physiological and psychological [10]. In general, physical education in elementary school is the beginning of the process of learning good and correct movement patterns to create a harmonious movement skill [11].

Learning motion skills at the elementary school level today, it turns out that the learning process of motion skills is still found using actual equipment (conventional) so that elementary school students experience obstacles or difficulties because 
they do not meet the abilities of children [12]. Therefore physical education learning cannot be done optimally. To overcome obstacles or difficulties in learning physical education (a teacher) must be able to find the right solution so that the goal of learning physical education is achieved one of them by playing [13]. Through play activities, it is appropriate to develop basic movement skills of children in primary school [14]. The world of children is a world of play meaning that every day children are always playing [15]. Games are one type of activity that is very popular with children because games can provide entertainment so that children feel happy and happy [16].

Considering the importance of movement patterns that make the basis of a movement in student education teachers must work on various movements that are developed for students who are more interesting and enjoyable [17]. The importance of basic movement patterns for students during the learning process at school, a professional teacher must be able to find the right solution so that the goal of learning basic motion skills can be achieved one of them by playing.

\section{METHOD}

\section{A. Research Design}

This research was carried out in ten public elementary schools in the Pontianak subdistrict area of the city. Beginning with an observation sheet for each sports teacher in the school, followed by inputting the results of the data based on actual data, and real so that it can categorize the success of each teacher in each school in the Pontianak subdistrict area of the city.

\section{B. The Scope of Research}

1) Types and forms of research: Based on the intent and purpose of this study, the type of method used in this study is a descriptive method. This method is intended to test a particular hypothesis, but only describes "as is" about a symptom, or condition. Descriptive research is not intended to test hypotheses.

The form of research used is survey research, namely the method of inquiry about the recurrence of events, events, and the environment that is carried out to obtain factual information in order (limited) to get information about variables by using instruments, such as observation sheets. To test a particular hypothesis, but only describes "as is" about a symptom, or condition. Descriptive research is not intended to test hypotheses.

The form of research used is survey research, namely the method of inquiry about the recurrence of events, events, and the environment that is carried out to obtain factual information in order (limited) to get information about variables by using instruments, such as observation sheets.

2) Subjects, objects and research data: State Elementary School 01 West Pontianak, State Elementary School 07 West Pontianak, State Elementary School 06 East Pontianak, State Elementary School 08 East Pontianak, State Elementary School 01 Pontianak Landmark, State Elementary School 05 Pontianak Landmark, State Elementary School 03 South
Pontianak, State Elementary School 09 South Pontianak Elementary School, State Elementary School 01 North Pontianak, State Elementary School 04 North Pontianak. There are 10 Public Elementary Schools in the Pontianak City District Area that were studied.

Research data obtained by researchers through observation in the location and recorded on the observation sheet of each teacher in each school. The data obtained includes several Observed Indicators so that they can find out the success of the teacher in carrying out the learning process.

3) Data collection technique:Data collection techniques are the most important factor in research because they relate directly to the data that will be used in research. In this study, researchers used direct observation techniques. Observation is direct observation. So that the data collection tool used is the teacher observation sheet.

4) Data analysis technique: The analysis used is descriptive. Descriptive statistics are statistics that function to describe or give an overview of the object under study through sample data or population as they are, without conducting analysis and making applicable to the public. The analysis used in this research is quantitative descriptive by classifying the types of data obtained from the observation sheet [18]. As for quantitative descriptive analysis with these percentages, the formula for processing the trial subject data is [19]:

$$
p=\frac{x}{x i} \times 100 \%
$$

Information :

- P : Percentage of evaluation results of trial subjects.

- $\mathrm{X}$ : Answer Number Subject Score Test.

- $\mathrm{Xi}$ : The maximum number of answers in the evaluation aspect of the trial subject.

- 100 : Constants.

TABLE I. STANDARD PERCENTAGE OF COMPLETION VALUE

\begin{tabular}{|l|l|}
\hline \multicolumn{1}{|c|}{ Range Of Norms } & \multicolumn{1}{c|}{ Category } \\
\hline $81-100$ & Very Good \\
\hline $71-80$ & Good \\
\hline $61-70$ & Enough \\
\hline $51-60$ & Less \\
\hline$<50$ & Very Less \\
\hline
\end{tabular}

\section{RESULTS AND DISCUSSION}

Based on the overall results of data analysis needs of 10 sports teachers conducted by researchers as a goal of developing a product, more details can be seen in the table below.

Based on the results of the study, to improve physical fitness in the learning process it should not be boring and the teacher should modify the teaching aids and choose the right method in applying the learning process so that it attracts students' attention, is active and enjoyable [20]. 
TABLE II.

TABLE 2. ReSUlts Of ANALYSIS Of NEEDS IN SPORTS TEACHERS

\begin{tabular}{|l|l|l|l|l|l|}
\hline No & School & $\begin{array}{c}\text { Top } \\
\text { Class }\end{array}$ & Score & $\begin{array}{c}\text { Completenes } \\
\text { s (\%) }\end{array}$ & Classification \\
\hline 1 & A 1 & 4 & 12 & 80 & Good \\
\hline 2 & A 2 & 5 & 10 & 67 & Enough \\
\hline 3 & A 3 & 6 & 10 & 67 & Enough \\
\hline 4 & A 4 & 4 & 11 & 73 & Enough \\
\hline 5 & A 5 & 5 & 10 & 67 & Enough \\
\hline 6 & A 6 & 6 & 9 & 60 & Less \\
\hline 7 & A 7 & 6 & 12 & 80 & Good \\
\hline 8 & A 8 & 4 & 11 & 73 & Enough \\
\hline 9 & A 9 & 5 & 11 & 73 & Enough \\
\hline 10 & A 10 & 4 & 10 & 67 & Enough \\
\hline
\end{tabular}

\begin{tabular}{clllll}
\hline Amount & & 49 & 106 & 706,63 & \\
Everage & 4,9 & 10,6 & 70,663 & Enough \\
\hline Min & & 4 & 9 & & \\
Max & & 6 & 12 & & \\
\cline { 1 - 3 } Very Good & $:$ & 0 & & \\
Good & $:$ & 2 & & \\
Enough & $:$ & 7 & & \\
Less & $:$ & 1 & & \\
Very Less & $:$ & 0 & &
\end{tabular}

From the results of the analysis as the needs of elementary school teachers in the Pontianak City area, it is known that the minimum value obtained is 9 while for the maximum value of 12 with 2 good category teachers, 7 category enough teachers, and 1 category teacher less overall value. Each school with an average grade of $70 \%$ is categorized as sufficient.

Therefore, it can be concluded from the preliminary study of sports teachers when conducting the learning process that requires new innovations and products, which are desired as guidelines, cooperative teaching materials and stages in accordance with the needs of school children, namely the floating learning model of basic motion skills based on games on high school elementary school children.

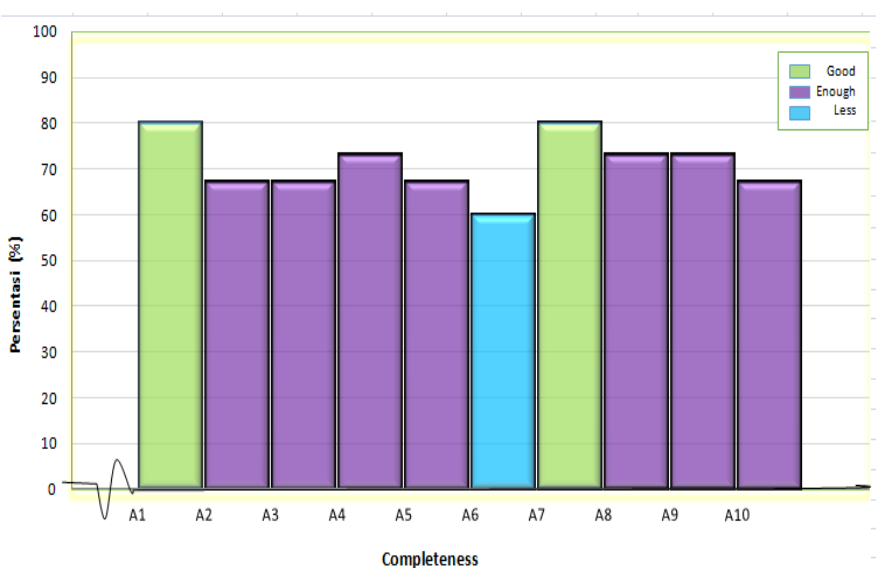

Fig. 1. Analysis of sports teacher needs.

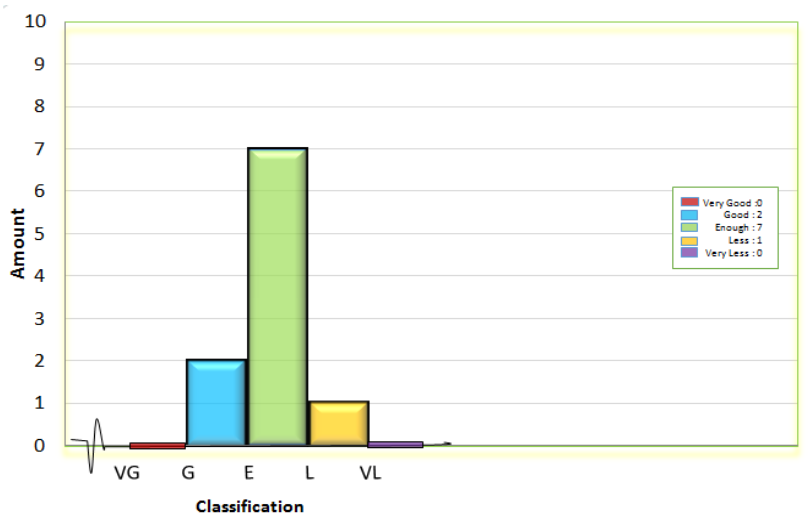

Fig. 2. Classification analysis of sports teacher needs.

\section{CONCLUSIONS}

Based on data analysis based on direct service in the field it can be concluded that 10 sports teachers from various Pontianak regions during physical education learning need innovation and new products.

The suggested conclusion is the need for game-based learning methods that innovate to create new products, which are needed as a guide, cooperative and competitive teaching material.

\section{REFERENCES}

[1] B. Dyson, "Towards cooperative learning in elementary school physical education," Journal of Physical Education Recreation and Dance, vol. 22(1), pp. 69-85, 2002.

[2] D. Kr Dixit and M. Shamim Ahmad, "Teacher education and life skills development towards global living citizenship," Conflux Journal of Education ISSN, vol. 1(2), pp. 2320-9305, 2013.

[3] J.T. Slobodzian, The C. of N. J, "A cross cultural study: deaf students in a public mainstream school setting," International Journal of Inclusive Education, vol. 15(6), pp. 649-666, 2011.

[4] National Association of State Boards of Education, "physical education policies," State School Health Policy Database, 2013.

[5] T. Kirjavainen, J. Pulkkinen and M. Jahnukainen, "Special education students in transition to further education: A four-year register-based follow-up study in Finland," Learning and Individual Differences, vol. 45 , pp. 33-42, 2016.

[6] J.M. De Oliveira, J.C.M. Jorge, J.B.F. Duarte, and V. H. C. de Albuquerque, "Complementary treatment for children with cerebral palsy based on virtual reality," Ieee Latin America Transactions, vol. 14(8), pp. 3820-3825, 2016.

[7] R.K.Y. Chong, "Comparison of muscle function during three contrasting abdominal exercises," Perceptual and Motor Skill, vol. 103(6), pp. 415 , 2006.

[8] J. Mcnamee, S. Bruecker, T. Murray, and C. Speich, "High-activity skills progression," Journal of Physical Education, Recreation \& Dance, vol. 78(7), pp. 17-32, 2007.

[9] O. Arikan, D.A. Forsyth, and J.F.O'Brien, "Motion synthesis from annotations," ACM Transactions on Graphics, vol. 22(3), pp. 402, 2003.

[10] C. Missiuna, N. Pollock, W. Campbell, L. Dix, S. Sahagian, and D. Stewart, "Partnering for change: embedding universal design for learning into school based occupational therapy," Occupational Therapy Now, vol. 17(3), pp. 13-15, 2015.

[11] H.R. Thompson, J. Linchey and K.A. Madsen, "Are physical education policies working? a snapshot from san francisco, 2011," Preventing Chronic Disease, vol. 10, p. 130108, 2013. 
[17] R.W. Heath, and M. a. Nielson, "The research basis for performancebased teacher education," Review of Educational Research, vol. 44(4), pp. 463-484, 1974.

[18] S.D. Aji, M. N. Hudha, C. Huda, A.B.D. Nandiyanto and A.G. Abdullah, "The improvement of learning effectiveness in the lesson study by using e-rubric," Journal of Engineering Science and Technology, vol. 13(5), pp. 1181-1189, 2018.

[19] Nana Sudjana, "Dasar-dasar proses belajar mengajar," Bandung, 2005.

[20] Hakim, L. Amiq, D.S. Fahrial Yudasmara, "Efforts to increase student activity in physical education learning using playing methods for students in class v sdn 2 pagelaran malang regency," Journal of Physical Education Teaching in Primary Schools, vol. 1 (2), pp. 65-77, 2018. 